\title{
Community Evaluation of Protected Areas Governance and Management Effectiveness: A Case Study of Manyara Region, Tanzania
}

\author{
Felix Joseph Mkonyi \\ Department of Biological Sciences, Dar es Salaam University College of Education, Dar es Salaam, Tanzania \\ Email address: \\ mkonyifj@gmail.com

\section{To cite this article:} \\ Felix Joseph Mkonyi. Community Evaluation of Protected Areas Governance and Management Effectiveness: A Case Study of Manyara \\ Region, Tanzania. International Journal of Natural Resource Ecology and Management. Vol. 3, No. 5, 2018, pp. 75-88. \\ doi: $10.11648 /$ j.jinrem.20180305.11
}

Received: September 21, 2018; Accepted: October 30, 2018; Published: November 28, 2018

\begin{abstract}
Protected areas (PAs) governance is increasingly seen as a critical determinant for PA management effectiveness. This paper aims to explore the actors involved in PA governance and management and their roles, and the factors influencing the PA management success as perceived by local communities in Manyara region, Tanzania. This study further explores the community perceptions of PAs governance using good governance principles including legitimacy and voice, accountability, performance, and fairness and rights. A mixed methods approach was used in this research which comprised structured household interviews, key informant interviews and document review. Respondents ranked local community involvement $(12.6 \%)$ and environmental education and awareness (13.8\%) as the top most important or relevant factors for PA management success in the region. Overall perceptions of respondents indicate that legitimacy and voice (83\%), fairness and rights $(75 \%)$ and performance $(68 \%)$ were the good principles of PA governance while transparency was the weak governance criteria which may undermine effective community participation in PAs management in the region. This study suggests the need for full involvement and coordination of many stakeholders including the local communities, integration of multilateral governance principles and improving environmental education and awareness for effective governance and management of PAs in the region.
\end{abstract}

Keywords: Good Governance, Governance Principles, Actors, Management, Manyara Region, Protected Areas (PAs), Tanzania

\section{Introduction}

Tanzania is richly endowed with biodiversity (including forests, national parks, game reserves and wetlands). Biodiversity is particularly important for the livelihoods of people living in rural areas. However, it faces many types of threats to its ecological integrity and cultural significance. Harmful practices to biodiversity originate from the failure of policies, laws and decision-making processes of the key actors. Human activities such as habitat destruction and fragmentation, over-exploitation or pollution are responsible for the ongoing decline in biodiversity, but these are linked with the absence or failure of management and governance structures and processes to deal with these developments [13]. Likewise, nature conservation experts confirm that problems at the operational level are closely linked with broader governance issues [4].

Protected areas (hereafter referred to as PAs) governance has emerged as a key theme in biodiversity conservation and PA management in particular $[5,6]$. However, one of the main challenges in the context of biodiversity conservation is largely rooted in the establishment of better governance and management approaches. Although governance and management of a PA are closely linked, they are distinct from each other [5]. Governance is defined as the institutions and processes used by right holders and stakeholders to make and influence decisions and to exercise authority and responsibility in society [7]. Governance is fundamentally about 'powers, authorities and responsibilities' exercised by organizations and individuals — addresses who make 
decisions de facto (in practice), and how these decisions are made - both at the level of individual PA sites and PA systems [8,9]. But, management addresses what is done about a particular site or situation and concerns 'the resources, plans and actions' that are a product of applied governance $[5,9,10]$. Four (out of five) principles of good governance (i.e. legitimacy and voice, performance, accountability, and fairness and rights) [8] and eight indicators of governance addressing public participation, transparency, accountability, responsiveness, equity, and rule of law [10] are used as the basis for analysis in this research. In this study, only some broadly-applicable indicators to PAs were selected and applied (Table 2). Good governance is essential for the effective management of PAs and must include these elements in order to recognize the interests of all key stakeholders.

The question of the integration of the social actors in the management of biodiversity is still largely under discussion in fundamental and applied research fields [11]. Few studies in Tanzania have examined the governance of PAs $[12,13]$, and there has been little work, if any, done to examine the role of key actors in PA governance and management in Manyara region, Tanzania. Yet, the factors influencing the PA management success are poorly understood and investigated in this region. This research aims to facilitate a better understanding of governance types, and analyze the ways existing systems of governance and groups of actors influence the management of PAs. It is hoped that the results generated in this study are of relevance to PA authorities, key actors and stakeholders at all levels - local, regional and national - and may influence better governance and management of PAs in the study region. Better governance might also improve PA outcomes, including improved conservation and community livelihood.

The complexity of governance issues involved in reconciling biodiversity-conservation with competing interests makes it difficult to manage PAs and the resources they contain. Given the pace of environmental degradation and biodiversity decline elsewhere [14], there is much to be gained from the key actors in PA governance and management and eventually assessing whether the forms of governance and management have been effective or not. The conservation success of PAs is dependent on the appropriateness of their management systems and broader governance issues such as their political and legal system, resource-use patterns as well as the degree of involvement of communities living within or nearby them [15]. This research adopted and tested a comprehensive set of factors to assess their relevance in influencing PA management success [15]. However, these factors have been slightly modified to suit the nature of this study (Table 1).

Specifically, the objectives of this study were to 1) identify the main actors of PA governance and management from the study region, the roles of these actors, and the interactions amongst governance actors in the region, 2) evaluate the perceived effectiveness of PA governance using the good governance principles, and 3) assess the factors perceived to be most important in influencing PA management success in the study region.

Table 1. List of factors (criteria) selected for testing PA management success.

\begin{tabular}{|c|c|c|}
\hline Governance context and social aspects & Management activities and management systems & External threats \\
\hline $\begin{array}{l}\text { Adequate national conservation policies and } \\
\text { programmes }\end{array}$ & $\begin{array}{l}\text { Practical conservation measures like reforestation, } \\
\text { protection against erosion }\end{array}$ & $\begin{array}{l}\text { Pressures on resources: commercial } \\
\text { exploitation of raw materials }\end{array}$ \\
\hline Political support at regional level & Outreach: rural development activities & Pressures on resources: tourism \\
\hline Local communities supporting the PAs & Outreach: environmental education/awareness activities & Pressures on resources: population increase \\
\hline Adequate funding & $\begin{array}{l}\text { Existence of PAs-specific rules and enforcement of these } \\
\text { rules }\end{array}$ & $\begin{array}{l}\text { Pressures on resources: proximity to human } \\
\text { settlement }\end{array}$ \\
\hline $\begin{array}{l}\text { Adequate institutional design: distribution of } \\
\text { responsibilities between authorities }\end{array}$ & $\begin{array}{l}\text { Involvement of local communities/community } \\
\text { participation }\end{array}$ & Pressures on resources: general poverty \\
\hline Clear boundary demarcation & $\begin{array}{l}\text { Long-term research, monitoring and evaluation for } \\
\text { adaptive management }\end{array}$ & $\begin{array}{l}\text { Conflict between political actors or } \\
\text { different population groups }\end{array}$ \\
\hline \multirow[t]{4}{*}{ Absence of corruption } & Adequate leadership & Climate change \\
\hline & Compensation for use restrictions & Invasive species \\
\hline & Effective mechanisms for conflict resolution & \\
\hline & $\begin{array}{l}\text { Maintenance of working relations/cooperation with local } \\
\text { authorities }\end{array}$ & \\
\hline
\end{tabular}

\section{Materials and Methods}

This study was conducted in four villages: Olasiti, Minjingu, Mwada and Riroda. These villages were selected based on the fact that they border PAs, and also based on the assumption that geographically adjacent communities will experience the greatest impacts arising from that area. Olasiti, Minjingu and Mwada are villages bordering the Tarangire National Park (TNP) and Lake Manyara National
Park (LMNP) while Riroda borders the Duru-Haitemba forest. Manyara region lies between latitudes $3^{\circ} 40^{\prime}$ and $6^{\circ} 0^{\prime}$ $\mathrm{S}$ and longitudes $33^{\circ}$ and $38^{\circ} \mathrm{E}$. The region has an area of 50,836 square kilometres $\left(\mathrm{km}^{2}\right)$ with $49,576 \mathrm{~km}^{2}$ of dry land and $1,260 \mathrm{~km}^{2}$ covered with water. The area consists of both consumptive and non-consumptive PAs. Consumptive PAs are designed to allow direct use of wildlife resources in the form of hunting (e.g. Game Reserves, Game Controlled Areas and Wildlife Management Areas) whereas nonconsumptive PAs are designed and managed for indirect uses 
such as game viewing and photographic tourism (e.g. National Parks) [16, 17].

The PAs network in Manyara region includes forest reserves, National Parks (TNP and LMNP), Game Controlled Areas (Lolkisale, Mto wa Mbu and Simanjiro) and Wildlife Management Areas (Burunge) (Figure 1). The forest reserves include the government forest reserves (i.e. forests owned by the government), the village forest reserves (i.e. forests owned and managed by the local communities), and those forests under Joint Forest Management (JFM). In Babati district, the government has declared 4 gazetted National forests managed by the forest department [18]. These include Ufiome, Nou, Bereko and Haraa. The Duru-Haitemba Forest Reserve is one of the forests managed by the local communities in Manyara region covering a total area of 9,000ha divided by eight village reserves, namely; Riroda, Sangara, Hoshan, Endagwe, Duru, Endanachan, Gida and Bubu [19]. In this study, structured questionnaires were administered to 120 randomly selected households to get local people's views and perceptions of PA management and governance. The sampling unit was the household and simple random sampling technique was used to identify those households. The sample included the head of the family (usually a man), the head's wife, or elder son according to seniority. Women often deferred to men, so respondents were predominantly male. Key informants included the following representatives: Park officials - TNP and LMNP $(\mathrm{n}=10)$, community-based organizations (CBO's) — Jumuiya ya Hifadhi ya Wanyapori Burunge (JUHIBU) organization representative $(\mathrm{n}=1)$, district officials (Environmental officer, Natural resources officer, Game officer, Beekeeping officer, Forest officer, District executive officer) $(n=6)$ and village officers (Village chairpersons) from seven villages (n $=7$ ). So a total of 24 key informants were involved. The questionnaire was pretested on a sample of 15 respondents, modified and adjusted to suit the situation on the field and to increase the questions' clarity. The questionnaire consisted of four thematic areas. The first thematic block was composed of socio-demographic characteristics of the respondents and factors related to governance and social aspects, the second one dealt with the factors related to management activities and management systems, and the third one explored the factors related to external threats on natural resources. The fourth thematic block dealt with principles of good governance (i.e. legitimacy and voice, accountability, performance, and fairness and rights).

The open and closed-ended questions were constructed following the principles of good governance. Respondents were asked to rank 26 factors with regard to their importance for the overall PA success. Responses to these questions were grouped into six categories: very high, high, low, somewhat, not at all and don't know. Respondents were also asked to highlight the factors (out of those listed) they thought were most important in influencing PA success. With regard to PA governance, the guiding questions were: 1) Are there opportunities for the public to be involved in PAs decisionmaking including planning? 2) Do the concerned rights holders and stakeholders have timely access to information related to conservation projects? 3) Are the governing institutions accountable or answerable to both higher and lower level stakeholders? 4) Are there checks and balances for ensuring accountability in PA management? 5) Do all men and women have a fair opportunity to improve or maintain their well-being within and outside the PA? 6) Are the costs and benefits of conservation shared fairly with all right holders and stakeholders impacted by PAs? 7) Do you think by-laws are fair and enforced impartially? 8) Are the governing institutions responsive to the needs of rights holders and stakeholders? The additional questions in this interview were 1) As a key stakeholder/actor of PAs governance and management, what are your main roles and responsibilities? 2) Could you please mention other stakeholders/actors involved in PAs governance and management in this area? 3) How do you interact (directly or indirectly) with other actors/stakeholders of PAs governance and management in this area?

The questionnaires were administered to household heads through face to face interviews between September and October 2008 and 2014. Interviews were conducted in a local language (i.e. Swahili language), translated back into English for better analysis and took approximately one hour to complete. Data was also collected from secondary sources including books, journal articles, policy and regulations, internet searches and consultancy reports in order to obtain in-depth information pertaining to a broad understanding of governance issues, biodiversity conservation and PAs management in the study area. Key informant interviews were used to collect information from a broad range of stakeholders to gain a better understanding of their perceptions and opinions concerning actors of PAs governance and management. In addition, key informants were asked to comment on the role-played or could be played by various actors (stakeholders) and their relationship to each other for the improved governance and management of PAs in the study area. Key informant interviews were conducted to supplement those collected through household questionnaire surveys.

Qualitative data and information from the discussion with key informants were analyzed through content analysis [20]. Content analysis was performed where raw data were condensed into categories or themes and patterns based on the interpretation obtained from the interview. Descriptive statistics (frequencies and computations of proportions in percentage) were used to compare statistical differences in responses among respondents. Quantitative data from completed household surveys were processed and analyzed using Statistical Package for the Social Sciences (SPSS) v. 22.0 (SPSS Inc., Chicago, IL, USA) at a significance level of $\mathrm{p}<0.05$. 


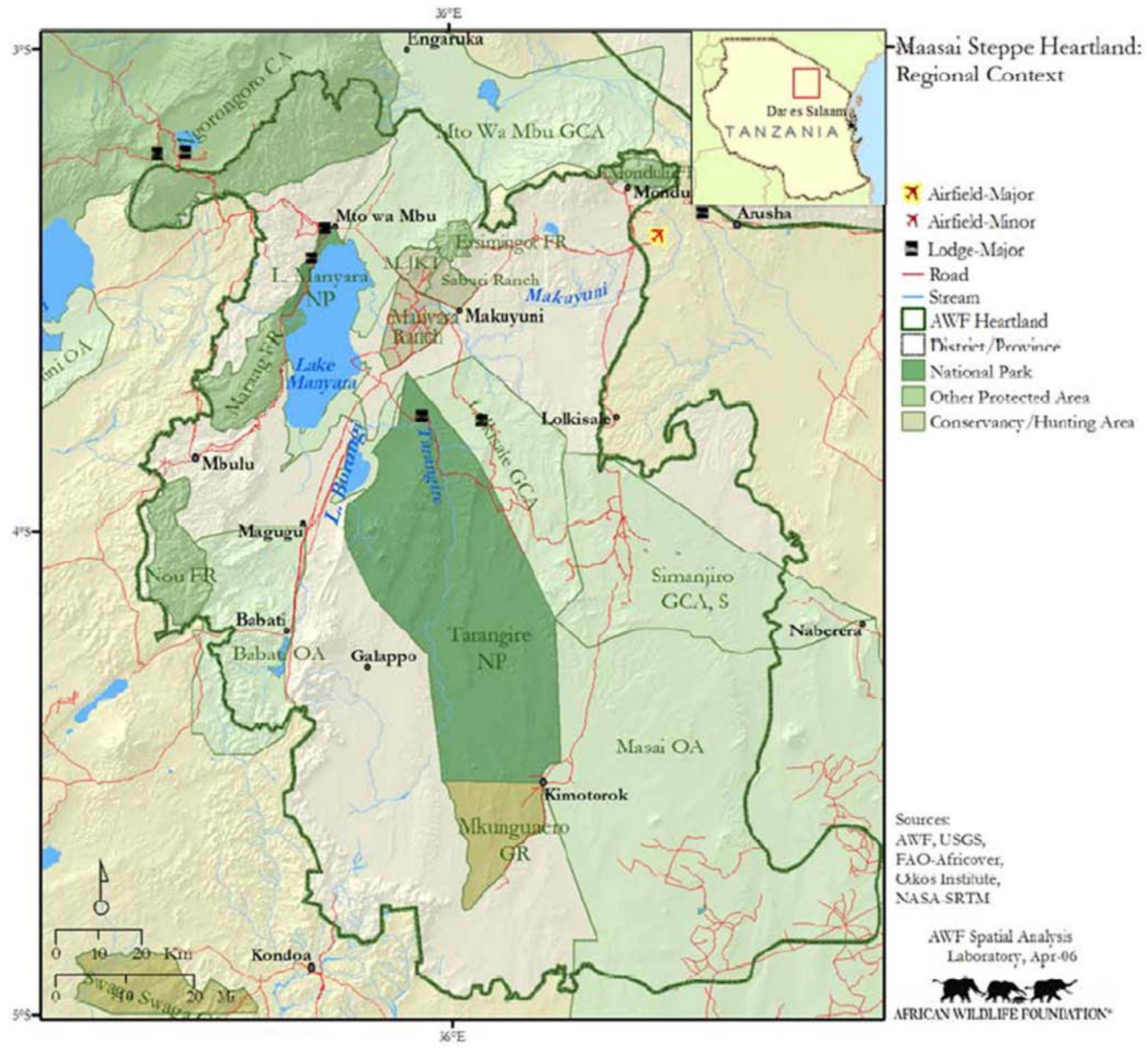

Figure 1. A map of the Maasai Steppe Ecosystem showing various grades of Pas.

\section{Results and Discussion}

\subsection{The Key Actors Involved in PA Governance and Management}

This study revealed the existence of several key actors of PA governance and management in the area, including the central government (Ministry of Natural Resources, and Tourism - MNRT; Forest and Beekeeping Division - FBD, Wildlife Division - WD), international conservation organizations (African Wildlife Foundation - AWF and World Wildlife Fund for Nature - WWF); academic institutions (University of Dar es Salaam — UDSM, Sokoine
University of Agriculture - SUA), researchers and research institutions (Tanzania Wildlife Research Institute TAWIRI); community-based organizations (e.g. JUHIBU), the local communities and local institutions. Overall, $60 \%$ of the respondents stated that the role of key actors in PA governance and management in the study area is highly recognized, while $6 \%$ stated that it is very highly recognized. Others stated that the role of key actors is either "somewhat recognized" (16\%), "not at all recognized" $(8 \%)$ or simply said that they "don't know" (10\%) (Figure 2). Results of the one sample t-test showed a significant difference between the respondents' perceptions and the role of key actors $(t=6.57$, $d f=4, p=0.003$, Figure 2). 


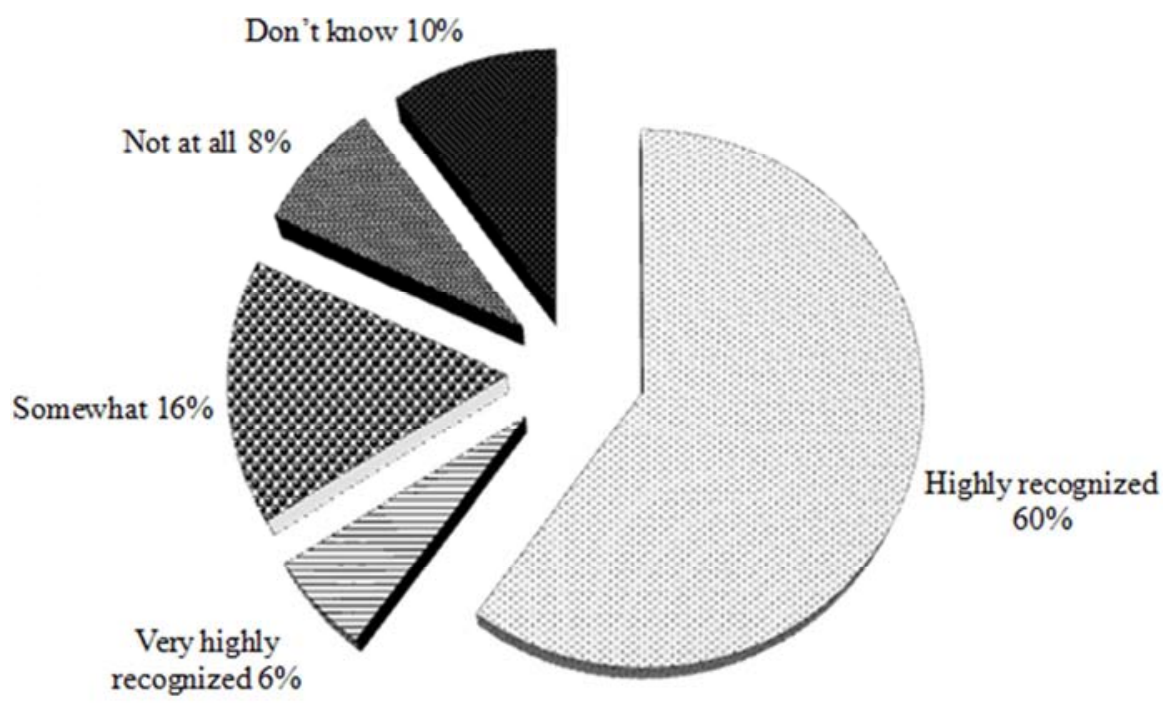

Figure 2. Respondents' perceptions on recognition of the role of key actors in PA governance and management in Manyara region, Tanzania.

\subsubsection{The Role of Tanzania National Parks Authority}

Tanzania National Parks (TANAPA) plays a significant role in the protection of biodiversity, ecological monitoring and creation of conservation awareness among the communities adjacent to the park and the general public (Lomi Ole Meikasi pers. Comm. 2008). TANAPA is a parastatal organization holding the authority, responsibility and accountability for the management of National Parks, determining the conservation goals and management objectives, making and enforcing management decisions. Wildlife inside the parks is fully protected under the National Parks ordinance, and outside the park wildlife management is covered by wildlife Act (1974) through the provision of community-based conservation (CBC). In 1985, TANAPA institutionalized $\mathrm{CBC}$ and began benefit sharing as part of a park outreach programme [21]. Currently, TANAPA runs its conservation activities through the CCS (Community Conservation Services) programme. This programme is aimed at identifying and implementing opportunities for sharing park benefits with adjacent communities and local governments. TANAPA through CCS programme interacts with local communities e.g. through supporting the local communities' development activities (e.g. building dispensaries, classrooms, roads, beekeeping projects). However, one of the respondents had a different opinion regarding the support received from TANAPA and explained that:

I think it is reasonable for [TANAPA] to continue supporting the [local communities] materially to accomplish their projects rather than through monetary form because this is overwhelmed by corruption. The 30\% of benefit accruing from tourism activities does not directly benefit the local communities.

- Respondent 50, a Maasai man

A few other stakeholders interact with TANAPA including tour operators, hunting companies, international conservation organizations (AWF and WWF), Manyara Ranch, Mweka Wildlife College, Wildlife division, village game scouts and
Ngorongoro conservation area.

\subsubsection{The Role of Local Communities}

Respondents considered the involvement of local communities as most important for achieving a more effective management of PAs in the region (see Figure 3). Local communities play a significant role in the maintenance of crucial ecosystem services including biodiversity, carbon sequestration and water resource management. Local communities' involvement in PA decision-making processes promotes a sense of ownership, where locals cooperatively protect reserves from outsiders and also regulate their own use of natural resources [22]. The 'sharing power' or integrated management planning approach emphasizes the implications of people participating in the protected areas' management processes and social benefits they will gain in return [23]. Therefore, it is important for the PAs management to respond to the local communities' livelihood needs. It is widely recognized that stable livelihoods around a PA are the best precondition for acceptance of userestrictions inside the Parks [24]. It is also obvious that people with poverty and absolute restriction of resource access will never have the positive attitude towards PAs [25]. However, promoting or securing stable local livelihoods is a long-term task which requires considerable capacity and resources [26]. Overall results from household surveys and key informant interviews showed that a lack of financial sustainability and adequate funding are the main challenging factors to PAs management. Also, adverse circumstances like corruption can affect the management and governance of PAs [27].

\subsubsection{The Role of Community-Based Organizations}

JUHIBU was the only community-based organization (CBO) identified in the study region. This organization is exclusively involved in wildlife conservation and benefit sharing in 9 villages in the region. In 2003, the government of Tanzania approved the Wildlife Management Area (WMA) regulations under section 84 of the Wildlife 
Conservation Act of 1974. The regulations allow communities to become corporate entities and participate in and benefit from wildlife utilization in WMAs. JUHIBU came into a full swing when the government decided to change Burunge Game Controlled Area into Burunge Wildlife Management Area in 2005 under the control of CBO's. In 2006, JUHIBU was certified and holds the authority of making and enforcing decisions on how wildlife should be managed over the 9 villages (Minjingu, Vilima vitatu, Kakoi, Magara, Sangaiwe, Mwada, Maweni, Manyara, Olasiti and Ngoley) constituting JUHIBU-Burunge WMA (Noah Teveli pers. Comm. 2008). These villages are interconnected by wildlife corridors for animals moving between Tarangire and Lake Manyara National Park (e.g. Kwakuchinja wildlife corridor). These villages obtain equal shares from money received from investors' campsites. The organization also receives a share (i.e. $25 \%$ ) from the hunting companies such as Northern Hunting Enterprises operating in Burunge WMA (Noah Teveli pers. Comm. 2008). However, the Game officer for Babati district explained to me that the organization has no authority over tourist hunting in WMAs; tourist hunting is managed by the central government (Nashon Makokecha pers. Comm. 2008). The basic rationale of introducing WMAs was that: WMAs would allow local communities to capture the benefits of wildlife in demarcated areas, and thus incentives for improved wildlife management in those areas would be established [28]. The wildlife corridor in the Tarangire-Manyara Ecosystem (i.e. Kwakuchinja wildlife corridor) is also protected and conserved by Ol Tukay conservancy organization. The Ol Tukai Conservancy protects and conserves a wildlife corridor while at the same time benefiting, empowering and educating the people of the Ol Tukai community.

JUHIBU under the well established environmental committee plays the following roles; makes a necessary follow up on environmental issues and advice better methods for biodiversity conservation in WMAs (Noah Teveli pers. Comm. 2008). Also, the committee makes sure that the conservation education is appropriately communicated to the local communities to minimize pressure on wildlife resources. The security committee provides security services including patrolling in WMAs. Moreover, the organization provides the coordination between the villages, local and central government. Key informant interviews and document review indicate that the organization interacts directly with the local and central government, international conservation organizations, village authorities, environmental activists and other actors in several ways such as through meetings and personal communications.

Previous analyses of community-based resource management show that this programme has slowed the loss of biodiversity while contributing benefits to the people [29]. It is further acknowledged that in order to maintain biodiversity and ecosystem services local communities should be given ownership or user rights to natural resources, allowed a greater share of the value added by sustainable management of the resources and should have greater say in decision-making relating to biodiversity management [29]. The ability of indigenous and local peoples to exercise their own governance structures is central to the success of community-oriented PA programmes [30]. In the case of Manyara region, local communities have taken responsibilities in the management of community forests what is commonly referred to as Community-Based Forest Management (CBFM), and management of wildlife on their lands an approach known as Community-Based Natural Resource Management (CBNRM). CBFM is the forest management system where local communities are both owners and duty bearers (that is, owners, users and managers of the forest) [31]. In CBFM, the local communities are the key decision makers during the planning and implementation processes [32]. The management rights and responsibilities of managing the forests are handed over to the local governments in a process of devolution [33]. A good experience of CBFM in the study region is that of DuruHaitemba village forest reserve in Babati District, the Oridoy village forest at Mwada village and Suledo community forest in Kiteto district. Between 1987 and 1992, the DuruHaitemba was under governmental control. However, this management proved inefficient and resulted in a decline in forest quality and loss of biodiversity. The power to manage these forests was delegated back to local communities in 1994 with eight villages sharing the responsibility of managing these forests. The amendments of the National Forest Policy of 1998, and also the establishment of new Forest Act of 2004 gave full mandate and authority to villages to establish their own village forest reserves. Therefore, in this circumstance, the village acts as 'the appropriate management institution' of the forest with each village managing a part of Duru-Haitemba forests. The purpose of this distribution is to empower specific villages to formulate close forest resource use controls, monitoring and evaluation. However, local communities through village forest management committees receive supervision from village government and work closely with the district officials who act as technical advisors and mediators for them to ensure proper use and good management of the forest. The Babati district has 82 villages with environmental committees in each village. Out of 82 villages, 45 villages have practiced community-based forest management with a total area of 34,166ha. The forest officer for Babati district explained to me that, out of 25,133 ha of government forest reserves, 24 villages practice JFM (Josian Maanga pers. Comm. 2008). However, through discussions with key informants, it was learned that the power given to the communities in JFM is limited and the participation is inadequate. This is due to the fact that the forest department has substantial control as a decision-making body in planning and management, allocation and demarcation of forest lands. This concurs with studies conducted elsewhere [34].

Although the impact of devolution and decentralization of forests to rural livelihoods is not systematically assessed in the area, the management of the forest reserves has improved considerably since the communities were given ownership of 
these forest reserves (Josian Maanga pers. Comm. 2008). Key informants reported that in this new approach of forest management where villagers act as 'forest managers' has been a very successful approach. One of the reasons that contributed to the success at Duru-Haitemba is linked to the full empowerment that is, the villagers have the right to devise their own institutions without being challenged by external government authorities [35]. Moreover, a previous study done around Duru-Haitemba forest reserve revealed that sustainable management of natural resources must rely exclusively on local communities [18]. First of all, the forest management and protection by the local communities has generated positive impacts whereby natural forest cover has improved in all 8 villages of Duru-Haitemba, and secondly, there has been an increase in forest regeneration and water sources [18]. Key informants reported that under village management, the villagers are now experiencing a low-level commercial exploitation of their forest. The local communities accrue some benefits from the forest such as timber harvesting under license, beekeeping projects, grazing activities, firewood collection, local medicines, mushrooms and stones [36]. The Oridoy village forest found in Mwada village is co-managed between the village government and JUHIBU (Noah Teveli pers. Comm. 2008). Villagers participate in the protection of Oridoy such that nonconsumptive use is practiced in this forest. Certainly, local communities will only participate in biodiversity management if they are persuaded that it is right and necessary to do so; when they have sufficient incentive, and the required knowledge and skills [37]. As transparency and empowerment are introduced to the villages, issues of mismanagement and corruption can be dealt with successfully as the village itself starts to exercise control. CBFM has been established in several other countries e.g. Botswana and Namibia [38], Zambia [39], Vietnam [40], Nepal [41], India [42], Philippines [43], USA [44], Mexico [45], China [46], Malawi, Kenya and Uganda [47, 48]. CBFM is widely considered as a management strategy aimed at reducing poverty, conserving natural resources and promoting good governance and decentralization [49].

On the other hand, community-based natural resource management (CBNRM) is a widespread approach to improving the biodiversity conservation and use of wildlife in sub-Saharan Africa [50, 51]. CBNRM is an approach to conservation and development that recognizes the rights of local people to manage and benefit from the management and use of natural resources. It entails transferring back to communities access and use rights, empowering them with legislation and devolved management responsibility, building their capacity and creating partnerships with the public and private sector actors to develop programmes for the sustainable use of a variety of natural resources [52]. CBNRM ensures that adequate land and local support is secured for biodiversity conservation and contributes to poverty alleviation in local communities living in landscapes with wildlife [53, 54]. CBNRM has been successfully implemented in some countries e.g. Zimbabwe [55],
Botswana and Namibia [56]. The transparency and accountability of governing institutions including rule of law have been critical to the successful implementation of CBNRM in these countries [56]. However, experience from the southern African regions demonstrates that in most cases governance issues in CBNRM have never been able to successfully go below the district level [57]. It is assumed that devolution of control over natural resources to local communities improves local governance through participation and hence empowers the poor [58]. The Wildlife Policy of Tanzania [28] calls for maintaining the core PAs - National Parks and Game Reserves — as the foundation of wildlife conservation in Tanzania, but advocates a devolved approach on village and private lands: It is the aim of this policy to allow rural communities and private landholders to manage wildlife on their land for their own benefit [28]. The new wildlife policy and legislation represents a shift from the former centralised approach (i.e. from government governance alone) to a decentralized approach (i.e. shared governance with local communities over wildlife resources outside of the PAs [28]. The mechanism for implementing this reform is accommodated in the WMAs. The WMAs regulations devolve authority to non-governmental 'CBOs' that are given user rights to wildlife.

In Tanzania, the impact of CBNRM on biodiversity is currently coupled with the increase in the population of indicator species such as elephants, reduction in poaching and improved vegetation and land cover [59]. The experience of CBNRM is considered as a vehicle for poverty reduction and achievements of Millennium Development Goals [60]. It is further acknowledged that poor governance, political marginalization and lack of access to natural resources prevent poor communities from managing them in a sustainable way [60]. Respondents from some communities complained to have been partially denied access to Burunge forest that is currently invested to a commercial hunting. It has been argued that loss of access to land and resources contribute to rural conflicts and the social-economic decline in communities dependent on park resources [61, 62]. However, community-oriented PAs can be used by local communities and indigenous peoples to aid in securing their territorial base, reaffirming cultural identities and guaranteeing some degree of autonomy over the governance of biological resources [63]. Nevertheless, the degree of effectiveness of the community forests must be linked to two basic factors i.e. the degree of ownership or tenure that communities may exercise over the resource and the transparency and accountability of local governance institutions [64].

\subsubsection{The Role of Local Institutions}

This study revealed the existence of both political and traditional institutions in the area. 'Qaymanda' is the traditional local institution that exists in the study region and it literally means ' $a$ sacred forest' used for secret social-ritual purposes such as initiation and sacrifices offerings. Fiome is 
a dominant tribe in Babati district, and they have set a special area within the Duru-Haitemba forests where they can perform their ritual activities. This area is completely protected and men are allowed to visit this area only under special circumstance for ritual purposes. At least 25 intact forest patches remain within the area with each patch not exceeding 3 acres. In that case, this institution has been successful in incorporating the indigenous knowledge in natural resources management and conservation of biodiversity. Other traditional local institutions such as 'Bokela' (a mountain God) and 'sacred trees' which function similarly to 'sacred forest' have been reported from local people living adjacent to Udzungwa National Park and Lake Manyara biosphere reserve respectively $[65,66]$. Such areas are treated as any other sacred places and are used as the specific places for worshiping, sacrifices offerings and other ritual purposes. Key informants reported the presence of political based local institutions such as village government and Village Environmental Committees (VEC) in each village. They take control of natural resources and management of biodiversity at the village level. The role of incorporating local institutions in the management and governance of biodiversity has been primarily addressed in specific areas [66]. It is widely recognized that the success of biodiversity conservation depends on the recognition and incorporation of indigenous knowledge and local institutions into government policies and programmes [65, 67]. Local institutions in Tanzania have been instrumental in natural resource management and rural development process [68]. The idea of local participation in conservation can be implemented through institutions and mechanisms and can range from passive participation to active participation [69]. The passive participatory approach is commonly known as 'Community Conservation' and the active participatory approach as 'Community-Based Conservation' [70].

\subsubsection{The Role of Central Government}

The central government under the MNRT plays a very significant role in PAs governance and management. The MNRT develop the management policies and ensure that the developed policies through its various divisions (e.g. FBD, WD, fisheries division) are implemented and communicated to the local government and local communities, and also holds the management authority to declare the PAs. The FBD is responsible for monitoring the implementation of the forest policy in collaboration with the local communities, conducting patrols on forest resources in collaboration with the communities and training on how to maintain forest and sustainable forest resources. Apart from that, the FBD is responsible for the provision of technical advice to the local communities on how to develop management plans and village forest by-laws. Moreover, the FBD sensitizes the local communities to construct local and modern beehives. Key informant interviews indicate that WD plays a very significant role in the governance and management and conservation of wildlife resources in the region. For instance, the WD is responsible for issuing guidelines on the implementation of the wildlife policy regarding WMAs [71]. It is mainly concerned with the protection and law enforcement within PAs. Moreover, the WD provides education to the local communities about wildlife management and ensures that crop plantation against wildlife damage is properly attained. However, the overall management of Game Reserves, Game Controlled Areas and all wildlife outside protected area boundaries and Wetlands is under the Tanzania Wildlife Authority (TAWA). In Tanzania, wildlife ownership is effectively monopolized by central government and contests between local and central actors over wildlife management is a widespread source of conflict in rural areas [28].

Key informant interviews and document review indicate that the wildlife sector interacts with other actors such as sports-hunting companies, photo-tourism operators and CBOs in integrated workshops, meetings with the village and central governments. The consumptive use of biodiversity includes tourist hunting, local hunting and fishing activities and non-consumptive use involves photographing, walking safaris and nature-based tourism 'ecotourism'. The central government interacts with several other stakeholders such as FARM Africa, LAMP, FIDE (Friends In Development) TRUST, Local Initiative Social Organization (LISO) and AWF, local communities, farm owners and local institutions.

\subsubsection{The Role of International Conservation Organizations and Donor Agencies, Academic Institutions, Researchers and Research Institutions}

The study revealed the existence of international conservation organizations and donor agencies such as AWF, WWF and SIDA, which work closely with the government, CBO's, research and training institutions and local communities. WWF, AWF and SIDA provide financial support to enhance biodiversity conservation in the region. Generally, AWF and WWF support biodiversity conservation in WMAs and the park. The academic, researchers and research institutions are mainly responsible for documentation of scientific information on biodiversity found in the PAs and build biodiversity database. Moreover, researchers are the best decision-makers and advisers on how biodiversity should be sustainably managed in those specific areas.

\subsection{PAs Governance and Governance Principles}

PA governance principles applied in this study included accountability, legitimacy and voice, performance, fairness and rights. The need for power-sharing with the participation of local communities and other stakeholders in the decisionmaking and planning processes was supported by the majority (see Table 2, Figure 3). Overall results from household surveys revealed that transparency is a weak governance criterion in the study region. However, over half of respondents $(53 \%)$ perceived that the governing institutions are accountable to stakeholders, but also there are checks and balances for ensuring accountability in PA management (69\%). 
Table 2. Respondents' perceptions of indicators of good governance $(n=120)$.

\begin{tabular}{|c|c|c|c|}
\hline \multirow{2}{*}{ Principles and Criteria of Good Governance } & \multicolumn{3}{|c|}{ Perception of respondents (number, \% in parentheses). } \\
\hline & 'Yes' & 'No' & 'Don't know' \\
\hline $\begin{array}{l}\text { Legitimacy and Voice } \\
\text { a) Public participation in decision-making including management planning } \\
\text { Accountability }\end{array}$ & $100(83)$ & $15(13)$ & $5(4)$ \\
\hline a) Transparency (stakeholders have timely access to information related to conservation projects) & $20(17)$ & $86(72)$ & $14(12)$ \\
\hline b) There are checks and balances for ensuring accountability in PA management & $80(67)$ & $28(23)$ & $12(10)$ \\
\hline $\begin{array}{l}\text { c) PA governing institutions are answerable or accountable to the stakeholders } \\
\text { Fairness and rights }\end{array}$ & $64(53)$ & $23(19)$ & $33(28)$ \\
\hline a) All men and women have opportunities to improve their well-being & $102(85)$ & $9(8)$ & $9(8)$ \\
\hline b) By-laws are fair and enforced impartially & $77(64)$ & $17(14)$ & $26(22)$ \\
\hline $\begin{array}{l}\text { c) Costs and benefits of conservation are shared fairly } \\
\text { Performance }\end{array}$ & $90(75)$ & $14(12)$ & $16(13)$ \\
\hline a) PA governing institutions are responsive to the needs of rights holders and stakeholders & $82(68)$ & $(13)$ & $23(19)$ \\
\hline
\end{tabular}

\subsection{Evaluation of Factors Influencing PA Management Success}

Figure 3 presents the 13 top factors considered most important or relevant for PA management success. Majority of respondents ranked the involvement of local communities $(12.6 \%)$ and the provision of environmental education and awareness $(13.8 \%)$ as 'top most important or relevant factors' for PA management success. The issues of communities supporting the PAs and absence of corruption were ranked third and fourth most important for PA success in the region, with each receiving a 'fair' rating of $11.7 \%$.
However, the factors such as adequate funding, adequate leadership, adequate institutional design, adequate national conservation policies and programmes, practical conservation measures, maintenance of working relations with local authorities, pressure on resources due to poverty, clear boundary demarcation and law enforcement were the least perceived factors receiving less than $10 \%$. When asked about the pressures on resources due to tourism, the majority of respondents $(65 \%, n=120)$ indicated that tourism activities have positive impacts on natural resources (i.e. positive impacts caused by tourism activities outweighed the negative ones).

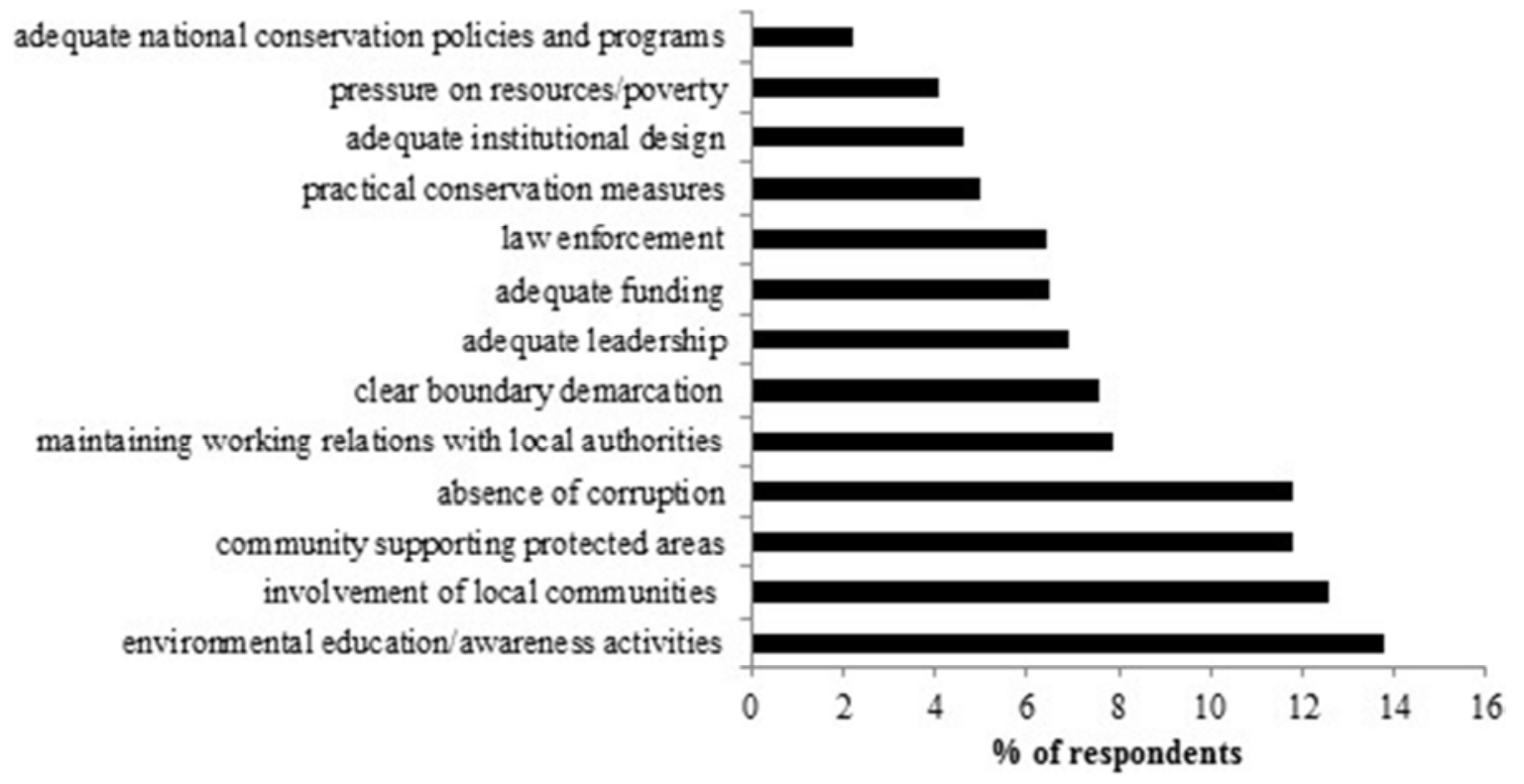

Figure 3. Respondents' perceptions of the most important factors for PA management success in Manyara region.

One of the primary requirements for successful conservation performance in PAs is that local communities should participate in the planning, decision making and management of the PA [30,65]. Effective participation requires an effort both from external PA stakeholders and from the communities themselves [72]. Participatory approaches have become nearly common in the management of PAs and conservation programmes [73], but challenges are said to arise in the management and co-management of PAs with local participation [74]. It is feared that local people are granted too much power that they do not possess the necessary competence and this could be an impact on global biodiversity and defined conservation needs [75].

The environmental awareness raising was ranked higher in this study which concurs with other studies $[26,27]$. The issues of communities supporting the PAs and absence of corruption emphasized in other findings [76], were ranked third and fourth most important for PA management success 
in the region. However, it is not enough for local communities to participate in PAs management processes but PAs should also be able to respond to local livelihood needs [26]. The respondents suggested that absence of corruption would be very relevant and this could lead to good governance and management of PAs surrounding them. Corruption is both a cause and an effect of poor governance [77]. Lack of good governance or weak governance may lead to corruption which can affect the success of conservation efforts $[4,78,79]$. Corruption reduces levels of international and national investment, lowers government spending on public services and favors the establishment of projects that allow the misappropriation of funds [80].

The governance aspects affecting the successful sustainable use of biodiversity in PAs have been categorized into dimensions of political embedding, institutional structures and related conflicts [27]. However, PAs management depends largely on the political interests with factors such as financial situation, support from political actors, effective networking, conflicting interests, the national conservation dialogue, the group of actors and the general political situation [27]. The involvement of local communities in the conservation of biodiversity is substantially based on their local knowledge, traditional and political institutions $[65,66]$. It is widely accepted that incorporating institutions increases the chance that policies once implemented will have the intended consequences of promoting conservation and sustainable use [26]. Conflicts can arise deliberately among the local population, (e.g. access and use of resources, use and property rights, tourism, ethnic groups); conflicts between the local population and PA management or state authorities, conservation against resource use activities like agriculture, poaching, logging, fishing or collection of medicinal plants, and conflicts about the legal status and financial compensations [4]. Key informants indicated that lack of compensation for animal damage on crops and livestock pose conflicts between local communities and PAs and this eventually demoralizes their initiatives to support conservation activities and hence, to difficulty in enforcing conservation policies. The same phenomenon has been reported in the western Serengeti in Tanzania [81].

Majority of respondents $(64 \%)$ perceived that fair enforcement of by-laws in PAs stand a better chance to prevent unsustainable exploitation of resources, but this may result in conflicts. The conflict over management of natural resources is the issue which was reported by one of the respondents as explained below:

There has been a conflict of interest between the local communities and the LMNP authority regarding the management of Marang Forest Reserve. The local communities want [this forest] to be managed by [them] through JFM while at the same time LMNP authority want [this forest] to be annexed to LMNP.

- Respondent 12, a Maasai man.

In addition, some respondents complained that restrictions in accessing resources from the park is the main source of conflict between local communities and PAs, as stated by one respondent:

Conflicts arise regularly when local communities are denied access to the campsites to collect fuelwood and palm leaves.

- Respondent 67, a Maasai man.

This suggests that local people's negative perceptions towards park officials may be attributed to restricted access to different resources from the park, a finding that has also been reported in other studies [82-84].

\section{Conclusion}

The aim of this paper was to explore the actors involved in PA governance and management and their roles, and the factors influencing the PA management success as perceived by local communities in Manyara region, Tanzania. The study shows that the role of key actors in PA governance and management is clearly recognized in the area and each of the identified actor or stakeholder had a specific role to play. Overall results suggest the need for community involvement and participation (in PAs planning, management and policymaking), environmental education and awareness and fighting corruption for achieving a more effective management of PAs in the region. Performance, fairness and rights, legitimacy and voice were perceived by respondents as the good principles of PAs governance, while transparency was the weak governance criteria for PAs management effectiveness in the study region. The management and governance of biodiversity outside PAs in the study area is viewed as a shift from the central government's interest (centralized approach) to the local communities' priorities (decentralized approach). The findings from this study further suggest that the $\mathrm{CBC}$ approach should be enhanced for improved governance and management of forest resources in the study region. Moreover, the village-based forest management system existing in the region is a good lesson to learn and should be a national and global movement. The Duru-Haitemba and Suledo case studies demonstrate that the management of forest in the rural areas would stand a better chance if local communities will have power over decisions, autonomy and sovereignty over their forest resources rather than having this imposed on them from the outside. From this experience, it indicates that CBFM is an important strategy for the management of forests in the study area, countrywide and global in particular. It is apparent that a CBNRM approach can help to address the drivers of biodiversity loss and poverty alleviation at the local level and achievements of the millennium development goals. This study further revealed that WMAs are a primary management mechanism for wildlife outside of PAs.

Evidence from household interviews and key informants suggest that accountability to the public should be strengthened in the study area and countrywide as a one step forward for PAs governance and management effectiveness. Local governments and local communities should be empowered and entrusted that they can bring changes to 
natural resource management; however, they should be assisted during the implementation process of their projects. Moreover, the benefits and costs of CBFM need to be critically analyzed but also the formulation of mechanisms for communities to capture the value of ecosystem services emanating from the management of forest resources need to be supported. A CBNRM is the best approach towards enhancing PAs by creating economic incentives for local communities to manage wildlife on their lands. CBOs are the key actors in PAs governance and management, but lack of technical capacity, weak management, conflict on benefit sharing and financial constraints are the main drawbacks facing these institutions. Therefore, effective governance and management of PAs in the region need the full involvement and coordination of many stakeholders including the local communities, integration of multilateral governance principles and improving environmental education and awareness.

\section{Acknowledgements}

This research was funded through a Research Programme on Sustainable Use of Drylands Biodiversity (no. 31-07-083 ). This research would not have been possible without the support and participation of the local communities, district and local government officials visited during this study. The author would like to appreciate their willingness to give their time to participate in this research. Special thanks also go to Vaileth Rigobert and Hawa Mosses for their utmost assistance during fieldwork. Thanks also go to all those who facilitated access to data and information.

\section{References}

[1] Brooks, T. M., Mittermeier, R. A., Mittermeier, C. G., da Fonseca, G. A. B., Ryland, A. B., Konstant, W. R., Flick, P et al. C. (2002). Habitat loss and extinction in the hotspots of biodiversity. Conservation Biology, 16: 909-923.

[2] Myers, N. (1993). Questions of mass extinction. Biodiversity and Conservation, 2: 2-17.

[3] Myers, N \& Knoll A. H. (2001). The biotic crisis and the future of evolution. Proceedings of the National Academy of Sciences of the United States of America, 98: 5389-5392.

[4] Smith, R. J. \& Walpole, M. J. (2005). Should conservationists pay more attention to corruption? Oryx, 39 (03): 251-256.

[5] Borrini-Feyerabend, G., Dudley N., \& Lassen B., S. T. (2013). Governance of protected areas: from understanding to action. Best practice protected area guidelines series No. 20. IUCN, Gland.

[6] Lockwood, M. (2007). Values and benefits. Managing protected areas: a global guide. London: Earthscan.

[7] Wilson, R., (2002). Private partners and the public good, Belfast. Available https://www.belfastfestival.com/schools/SchoolofLaw/Resear ch/InstituteofGoverna nce/Publications/.
[8] Graham, J, Amos, B \& Plumptre, T., (2003). Governance principles for protected areas in the 21st. century. Fifth World Parks Congress, South Africa in September 2003.

[9] Lockwood, M., Davidson, J., Curtis, A., Stratford, E., \& Griffith, R. (2010). Governance principles for natural resource management. Society and Natural Resources, 23: 986-1001.

[10] Abrams, P.; Borrini-Feyerabend, G.; Gardner, J \& Heylings, P. (2003). Evaluating governance: A handbook to accompany a participatory process for a protected area. draft for field testing, Parks Canada and TILCEPA; Retrieved from http://www.iucn.org/about/union/commissions/ceesp/topics/go vernance/shared.cfm. Accessed on May 21, 2018.

[11] Moreno, P. (2005). An organizational approach for the biodiversity management by local communities in developing countries. Judge institute of management studies, Cambridge.

[12] Kisingo, A. W. (2013). Governance of protected areas in the Serengeti ecosystem, Tanzania. Ph.D. Dissertation. University of Victoria, Canada.

[13] Kisingo, A., Rollins, R., Murray, G., Dearden, P., \& Clarke, M. (2016). Evaluating 'good governance': the development of a quantitative tool in the Greater Serengeti Ecosystem. Journal of Environmental Management, 181: 749-755.

[14] Rands, M. R. W., Adams, W. M., Bennun, L., Butchart, S. H. M., Clements, A., Coomes, D., Entwistle, A et al. (2010). Biodiversity conservation: challenges beyond 2010. Science, 329 (5997): 1298-303.

[15] Stoll-Kleemann, S. (2004). Indicators and evaluation of sustainable natural resource management and governance in Biosphere Reserves. Second Thematic Workshop: Projecting Global Change Impacts in Mountain Biosphere Reserves. Gran Sasso National Park. 29 November-2 December 2004.

[16] URT (United Republic of Tanzania). (2009a). The wildlife conservation act., Pub. L. No. 5. Tanzania.

[17] URT (United Republic of Tanzania). (2009b). Wildlife Conservation Act (Non-consumptive use regulations).

[18] Rwiza, A. (2002). Community-based forest management. a case study of Duru-Haitemba forest in Babati district, Tanzania. (Unpublished report).

[19] Kajembe, G. C. \& Mgoo, J. S. (1999). Evaluation report on community-based forest management approach in Babati District: a case of Duru-Haitemba village forest reserve. Orgut Consulting AB (Unpublished).

[20] Patton, M. Q. (1990). Qualitative evaluation and research methods. Sage Publications, Newbury Park.

[21] Bergin, P. J. (1995). Conservation and development: the Institutionalization of community conservation in Tanzania National Parks. School of Development Studies. Norwich, UK, University of East Anglia: 198.

[22] Andrade, G. S. M. \& Rhodes, J. R. (2012). Protected areas and local communities: an inevitable partnership toward successful conservation strategies? Ecology and Society, 17 (4):14.

[23] Thomas, L. \& Middleton, J. (2003). Guidelines for management planning of protected areas. United Kingdom: Cardiff University. IUCN Gland, Switzerland and Cambridge $\mathrm{x}+79 \mathrm{pp}$. 
[24] Stoll-Kleemann, S. (2006). Barriers and success factors for implementing mechanisms for sustainable use of biodiversity. The Sustainable harvest of non-timber forest products in China. Strategies to balance economic benefits and biodiversity conservation. Symposium proceedings, SinoGerman Symposium.

[25] Dorji, R. (2009). Interactions between protected areas and local communities. a case study from Jigme Dorji National Park, Bhutan, University of Natural Resources and Applied Life Sciences, Vienna, Austria.

[26] Stoll-Kleemann, S. (2005). Voices for biodiversity management in the 21st century. Environment; 47 (10): 2436.

[27] Stoll-Kleemann, S., Bender, S., Berghöfer, A., Bertzky, M., Fritz-Vietta, N., Schliep, R. \& Thierfelder B. (2006). Linking governance and management perspectives with conservation success in protected areas and Biosphere Reserves. GoBi Discussion Paper Series No. 1, Humboldt University of Berlin, Berlin.

[28] MNRT (Ministry of Natural Resources and Tourism). (1998b). The Wildlife Policy of Tanzania. Dar es Salaam: Government Printer.

[29] Abensperg-Traun, M., Roe, D. \& O'Criodain, C., eds. (2011). CITES and CBNRM. Proceedings of an international symposium on "The relevance of CBNRM to the conservation and sustainable use of CITES-listed species in exporting countries", Vienna, Austria, 18-20 May 2011. Gland, Switzerland: IUCN and London, UK: IIED. 172pp.

[30] Badola, R., Barthwal, S. \& Hussain, S. A. (2012). Attitudes of local communities towards conservation of mangrove forests: A case study from the east coast of India. Estuarine, Coastal and Shelf Science, 96: 188-196.

[31] Alden Wily, L. (1997). Villagers as forest managers and government 'learning to let go'. the case of Duru-Haitemba and Mgori forests in Tanzania. London: Institute of International Development. (Forest participation series; no. 9.)

[32] Murphree, M. W. (2009). The strategic pillars of communal natural resource management: benefit, empowerment and conservation. Biodiversity and Conservation, 18:2551-2562.

[33] Ribot, J. (2002). Democratic Decentralization of Natural Resources: Institutionalizing Popular Participation. World Resources Institute: Washington, DC.

[34] Bhattacharya, P., Pradhan, L., \& Yadav, G. (2010). Joint forest management in India: experiences of two decades. Resources, Conservation and Recycling, 54 (8): 469-480.

[35] Kajembe, G. C, Monela, G. C \& Mvena, Z. S. K. (2003). Making community-based forest management work: a case study from Duru-Haitemba village forest reserve, Babati, Tanzania. In Policies and governance structures in woodlands of southern Africa, edited by G Kowero, BM Campbell and UR Sumaila. Jakarta: Center for International Forestry Research:16-27.

[36] Malimbwi, R. E. (2003). Inventory reports of Ayasanda, Bubu, Duru, Endagwe, Endanachan, Gidas, Hoshan and Riroda Village Forest Reserves in Babati, Manyara, Tanzania. Manyara, Tanzania: Land Management Programme, Babati District Council.

[37] NEP (National Environmental Policy). (1997). The United
Republic Of Tanzania.

[38] Alden Wily, L. (2003). Community forest management in Africa progress and challenges in the 21st century in FAO 2003.

[39] Lukama, B. (2000). Participatory forest management: a strategy for sustainable forest management in Africa. a case study of the Chinyunyu Community Forestry Project, Zambia. In FAO 2000a.

[40] Nguyen, T. Q. (2005). 'What benefits and for whom? Effects of devolution of forest management in Dak Lak, Vietnam.' In V. Beckmann and K. Hagedorn (eds). Shaker Verlag: Aachen, Germany.

[41] Acharya, K. P. (2003). Conserving biodiversity and improving livelihoods: the case of community forestry in Nepal. Proceedings of International Conference on Rural Livelihood, Forests and Biodiversity, Centre for International Forestry Research, 19-23 May 2003, Bonn.

[42] Sreekesh, S., Vashist U. S. \& Kurian M. (1998). Property rights and sustainable forest management: case study from Haryana State, North West India. The World Bank/WBI's CBNRM Initiative.

[43] Gollin, K. L. \& Kho J. (2002). Rethinking community, participation, and power in Philippine CBNRM. Manila: Ford Foundation.

[44] Barret, C. B; Brandon, K; Gibson, C \& Gjertsen, H. (2001). Conserving tropical biodiversity amid weak institutions. Bioscience, 51: 497-502.

[45] Bray, D. B. \& Merino-Perez, L. (2002). The rise of community forestry in Mexico: history, concepts, and lessons learned from twenty-five years of community timber production.

[46] Lai, C. K. \& Lanying Z. (2002). A decade of discovery: An external review of Ford Foundation work with the Forestry Departments of Yunnan and Sichuan Provinces, Southwest China. Beijing: Ford Foundation.

[47] Mazur, R. E. \& Stakhanov O. V. (2008). Prospects for enhancing livelihoods, communities, and biodiversity in Africa through community-based forest management: a critical analysis. Local Environment, 13 (5): 405-421.

[48] Turyahabwe N; Geldenhuys C. J; Watts S. \& Obua J. (2007). Local organizations and decentralized forest management in Uganda: roles, challenges and policy implications. International Forest Review, 9 (2): 581-596.

[49] Danida, (2004). Danida's annual Development Co-operation Report, 2004/ Danida’s årsberetning 2004.

[50] Awimbo, J., Barrow E. G. C \& Karaba, M. (2004). Community-based natural resource management in the IGAD region. 249pp.

[51] Hulme, D. \& Murphree, M.. (2001). African wildlife and livelihoods: the promise and performance of community conservation. Oxford: James Currey Ltd.

[52] Armitage, D. (2005). Adaptive Capacity and CommunityBased Natural Resource Management. Environmental Management, 35:703-715.

[53] Murphree, M. W. (1993). Communities as resource management institutions. International Institute for Environment and Development, Gatekeeper Series No. 36. 
[54] Western, D. (1994). Ecosystem conservation and rural development: the case of Amboseli. Natural Connections: Perspectives in Community-Based Conservation. D. Western, R. M. Wright and S. Strum. Washington, DC: Covelo, CA, Island Press: $15-52$.

[55] Conyers, D. (2002). Whose elephants are they? Decentralization of control over wildlife management through the Campfire programme in Binga district, Zimbabwe. Working Paper No. 4. World Resources Institute.

[56] Nelson, F. (2006). Patronage or participation? Understanding the failure and success of community-based natural resource management reforms in Sub-Saharan Africa. School of Natural Resources and Environment University of Michigan.

[57] Mujakachi, L. (2000). Institutional issues and the governance of CBNRM: some lessons from the SADC Natural Resources Management Programme. Presentation at the $2^{\text {nd }}$ Regional Meeting 'CBNRM in Southern Africa' held at the School of Government, University of the Western Cape, South Africa, 16-17 October 2000.

[58] Campell, T. (2006). Devolved natural resource management as a means of empowering the poor: rhetoric or reality? TrÓcaire Development Review, Dublin. Pp. 117-133.

[59] Sosovele, H. (2007). Establishing wildlife management areas (WMAs): Impacts of CBNRM on biodiversity and communities in Tanzania. Proceedings on the workshop between the Africa Biodiversity Collaborative Group (ABCG) and Frame held at WWF, Washington, DC.

[60] Jones, B. T. B. (2004). Synthesis of the current status of CBNRM policy and legislation in Botswana, Malawi, Mozambique, Namibia, Zambia and Zimbabwe. Harare: WWF Southern African Regional Programme Office.

[61] Neumann, R. (1998). Imposing wilderness: struggles over livelihood and nature preservation in Africa. Berkeley, California, University of California Press.

[62] Norton-Griffiths, M. (1995). Economic incentives to develop the rangelands of Serengeti: implications for Wildlife Conservation. Serengeti II: Dynamics, Management, and Conservation of an Ecosystem. A. R. E. a. A. P. Sinclair. Chicago, University of Chicago Press. II: 588-604.

[63] Langton, M., Rhea, M. Z., \& Palmer L., (2005). Communityoriented protected areas for indigenous peoples and local communities. Journal of Political Ecology, 12 (1): 23-49.

[64] Blomley, R., Nelson F., Martin A \& Ngobo M. (2007). Community conserved areas. a review of status and needs in selected countries of central and eastern Africa. A Draft report.

[65] Kajembe, G. C \& Mbwambo, J. S. (2000). The role of local institutions in biodiversity conservation: a case study of Udzungwa Mountains Tanzania. In: Shemwetta, D. T. K and Ngaga, Y. M (Edds). Proceedings of the workshop on 'Operationalization of forest policy: Opportunities and Challenges' Sokoine University of Agriculture Tanzania 36-56 p.

[66] Shemdoe, R. S. (2003). The role of local institutions in the management of biodiversity: a case study of Lake Manyara National Park, Tanzania. Research report. UNESCO-MAB Young Scientist Programme.

[67] Gadgil, M., Berkes F. \& Folke, C. (1993). Indigenous knowledge for biodiversity conservation. Ambio, 22 (2-3): 151-156.
[68] Kajembe, G. C., Kimasa, S. F., Monela, G. C \& Zahabu, E. (2000). The role of local institutions in the management of forest resources in Tanzania: a case study of Kahama District. Tanzania Journal of Forest and Nature Conservation, 73:9-16.

[69] Pimbert, M. P \& Pretty J. N. (1997). Parks, people and professionals: putting 'participation' into protected area management. In: Ghimire BK, Pimbert MP, editors. Social Change and Conservation. London, UK: Earthscan.

[70] Songorwa, A. N., Bührs, K. \& Hughey, K. (2000). Community-based wildlife management in Africa: a critical assessment of the literature. Natural Resources Journal, 40 (2): 603-643.

[71] MNRT (Ministry of Natural Resources and Tourism). (2002b). The Wildlife Conservation (Wildlife Management Areas) Regulation. Dar es Salaam: Government Printer.

[72] Poudel, C. B. (2007). Governance vs accountability: a case of protected area management with people's participation in Nepal. IUFRO Division VI Symposium Integrative Science for Integrative Management (14-17 August 2007).

[73] Agrawal, A. \& Gibson, C. C. (1999). Enchantment and disenchantment: the role of community in natural resource conservation. World Development, 27:629-649.

[74] Baker, M \& Kusel J. (2003). Community forestry in the United States: learning from the past, crafting the future. Washington, DC: Island Press. 247 pp.

[75] Oates, J. F. (1999). Myth and reality in the rainforest: how conservation strategies are failing in West Africa. Berkeley, CA: University of California Press.

[76] Stoll-Kleemann, S; Thierfelder B; Bertzky M \& Bergh offer A. (2004). Governance and biodiversity linking conservation success with management perspectives. The case of Biosphere Reserves. Rural Poverty Reduction through Research for Development' Humboldt-Universität zu Berlin, Institute of Agricultural Economics and Social sciences (IWSL), GoBi Research Group, Germany.

[77] Gordon, G \& Lawson, M. (2012): Why advocate on governance and corruption? Tearfund. Teddington, UK.

[78] Sandker, M., Campbell, B. M., Nzooh, Z., Sunderland, T., Amougou, V., Defo, L. \& Sayer, J., (2009). Exploring the effectiveness of integrated conservation and development interventions in a Central African forest landscape. Biodiversity and Conservation, 18 (11): 2875-2892.

[79] Smith, R. J., Muir, R. D. J., Walpole, M. J., Balmford, A. \& Williams Leader- N. (2003). Governance and the loss of biodiversity. Nature, 426: 67-70.

[80] Azfar, O., Lee, Y. \& Swamy, A. (2001). The causes and consequences of corruption. The Annals of the American Academy of Political and Social Science, 573: 42-56.

[81] Emerton, L. \& Mfunda I. (1999). Making wildlife economically viable for communities living around the Western Serengeti, Tanzania. Evaluating Eden Series Discussion Paper No. 1. London: International Institute for Environment and Development.

[82] Kideghesho, J. R., Røskaft, E. \& Kaltenborn, B. P. (2007). Factors influencing conservation attitudes of local people in Western Serengeti, Tanzania. Biodiversity and Conservation, 16:2213-2230. 
Felix Joseph Mkonyi: Community Evaluation of Protected Areas Governance and Management Effectiveness:

A Case Study of Manyara Region, Tanzania

[83] Khumalo, K. E. \& Yung, L. A. (2015). Women, HumanWildlife Conflict, and CBNRM: Hidden Impacts and Vulnerabilities in Kwandu Conservancy, Namibia. Conservation and Society, 13: 232.

[84] Mfunda, I. M., Holmern, T. \& Røskaft, E. (2012). Benefits and access to natural resources influence conservation perceptions and relationship between local people and other stakeholders: The case of Serengeti ecosystem, Tanzania. International Journal of Biodiversity and Conservation, 4: $535-547$. 